\title{
Spontaneous Larval Gnathostoma nipponicum Infection in Frogs
}

Takashi OYAMADA, Tetsuya HIRATA, Meguru HARA, Noboru KUDO, Toshifumi OYAMADA ${ }^{1)}$, Hiroyasu YOSHIKAWA ${ }^{1)}$, Takashi YOSHIKAWA ${ }^{1)}$ and Naoyoshi SUZUKI

Departments of Veterinary Parasitology and ${ }^{1)}$ Veterinary Pathology, School of Veterinary Medicine and Animal Sciences, Kitasato University, Towada, Aomori 034-8628, Japan

(Received 11 March 1998/Accepted 18 May 1998)

ABSTRACT. From June 1993 to September 1997, a survey was carried out for the prevalence of larval Gnathostoma nipponicum infection in several kinds of frogs, toads, and their tadpoles collected from an endemic area of this nematode in Aomori Prefecture. Two frog species, one of $436(0.2 \%)$ Rana nigromaculata and 51 of 147 (34.7\%) R. catesbeiana were infected, and a total of 446 advanced thirdstage larvae (AdL3) of G. nipponicum were recovered. These results confirmed that two frog species which can serve as the second intermediate and/or paratenic hosts in the life cycle of $G$. nipponicum exist in nature. This report is the first record of spontaneous infection of frogs with AdL3 of G. nipponicum. - KEY wORDS: advanced third-stage larva, Gnathostoma nipponicum, intermediate host. J. Vet. Med.Sci. 60(9): 1029-1031, 1998

In Japan, Gnathostoma nipponicum, which is a common parasite found in weasels [14, 17], is a zoonotic parasite [3, 16]. Although the life cycle of this nematode is not completely cleared, it has been confirmed experimentally that two intermediate hosts are required, i.e., some species of copepods can serve as the first intermediate host and various species of animals including frogs can serve as the second intermediate and/or paratenic hosts $[2,7,9]$. In the past, spontaneous infection of advanced third-stage larvae (AdL3) of this nematode have been recorded from freshwater fish (five species), reptiles (two species) and small mammals (two species), and these animals were regarded as the second intermediate and/or paratenic hosts in nature $[3,7,10-15]$. Up to now, no amphibians including frog species naturally infected with AdL3 of G. nipponicum have been found. However, some frogs of the genus Rana naturally infected with larvae have been recorded from $G$. spinigerum [9], i.e., R. nigromaculata and $R$. catesbeiana, and from $G$. doloresi $[4,5]$, i.e., R. (Babina) subaspera, $R$. narina, $R$. ishikawae, and $R$. namyei. In addition, experimental studies had revealed that several species of frogs and toads had larval infection of $G$. spinigerum [6], i.e., R. nigromaculata, $R$. catesbeiana, R. Rugosa, Hyla arvorea japonica, and Bufo vulgaris formosus, and of $G$. hispidum [1, 8], i.e., $R$. nigromaculata and $R$. limnocharis. Based on these reports and the results of our previous surveys, we hypothesised that weasels, the final host, might also be infected with $G$. nipponicum by preying on amphibians, such as frogs.

In the present study, we carried out a survey for the prevalence of larval G. nipponicum infection in frogs, toads, and their tadpoles collected from eastern Aomori Prefecture, an endemic area of this nematode [10-15].

From June 1993 to September 1997, a total of 7,169 frogs, toads, and their tadpoles including the following six species (Table 1), Hyla japonica, Rana ornativentris, $R$.

Table 1. Prevalence of Gnathostoma nipponicum larvae in frogs, toads, and tadpoles collected from June 1993 to September 1997 in eastern Aomori Prefecture

\begin{tabular}{lcccc}
\hline \multirow{2}{*}{ Examined species } & \multicolumn{2}{c}{ No. specimens } & No. larvae \\
\cline { 2 - 5 } & examined & infected (\%) & $\begin{array}{c}\text { No. larvae } \\
\text { recover infected } \\
\text { frog (mean) }\end{array}$ \\
\hline Frog and toad & & & & \\
$\quad$ Hyla japonica & 431 & 0 & & \\
$\quad$ Rana ornativentris & 434 & 0 & & $1(1.0)$ \\
$\quad$ Rana nigromaculata & 436 & $1(0.2)$ & 1 & $1-95(8.7)$ \\
Rana rugosa & 427 & 0 & & \\
$\quad$ Rana catesbeiana & 147 & $51(34.7)$ & 445 & \\
$\quad$ Bufo japonicus formosus & 31 & 0 & & \\
\hline Total & 1,906 & & 446 & \\
\hline Tadpole & & & & \\
$\quad$ Rana catesbeiana & 587 & 0 & & \\
$\quad$ Rana spp. & 4,676 & 0 & & \\
\hline Total & 5,263 & & & \\
\hline
\end{tabular}


Table 2. Relationship between the body length of bullfrog (Rana catesbei$a n a)$ and prevalence of Gnathostoma nipponicum larvae

\begin{tabular}{|c|c|c|c|c|c|}
\hline \multirow{2}{*}{$\begin{array}{l}\text { Range of } \\
\text { frog body } \\
\text { length }(\mathrm{cm})\end{array}$} & \multicolumn{2}{|c|}{ No. frogs } & \multirow{2}{*}{$\begin{array}{c}\text { Prevalence } \\
(\%)\end{array}$} & \multirow{2}{*}{$\begin{array}{l}\text { No. larvae } \\
\text { recovered }\end{array}$} & \multirow{2}{*}{$\begin{array}{l}\text { No. larvae } \\
\text { per infected } \\
\text { frog (mean) }\end{array}$} \\
\hline & examined & infected & & & \\
\hline$\leqq 8.0$ & 20 & 1 & 5.0 & 1 & $1(1.0)$ \\
\hline $8.1-10.0$ & 18 & 2 & 11.1 & 2 & $1(1.0)$ \\
\hline $10.1-12.0$ & 38 & 7 & 18.4 & 19 & $1-12(2.7)$ \\
\hline $12.1-14.0$ & 28 & 8 & 28.6 & 39 & $1-23(4.9)$ \\
\hline $14.1 \leqq$ & 43 & 33 & 76.7 & 384 & $1-95$ (11.6) \\
\hline Total & 147 & 51 & 34.7 & 445 & $1-95(8.7)$ \\
\hline
\end{tabular}

nigromaculata, R. rugosa, R. catesbeiana, and Bufo japonicus formosus, were collected. For larval infection, all animals were examined with an artificial digestion described in previous our report [13]. Prior to digestion, each animal was weighed and body size was measured. In all $R$. catesbeiana, the stomachs were examined to find ingested food, and each frog was divided into six parts, i.e., hypodermis, head, visceral organs, and three portions of musculature (frontal legs, posterior legs, and thoracoabdominal wall) to determine the location of the larvae. In addition, muscle tissues of legs and thoraco-abdominal walls in three $R$. catesbeiana were examined after pressing between two thick glass plates before digestion. The recovered larvae (except for the experimental infection to laboratory mammals) were readily fixed with $10 \%$ hot formalin, cleared and mounted with lactophenol for morphological observation. Three rats (Wistar: male), four mice (ddY: male), and three golden hamstars (Syrian: male) were inoculated orally with larvae (10 or 20 per animal) obtained from $R$. catesbeiana, to find the infectivity of the larvae to mammals. All animals were examined at 30 days postinoculation.

In the field survey, as shown in Table 1, spontaneous infection of gnathostome larvae were found in two frog species, $R$. nigromaculata (common name: pond frog) and $R$. catesbeiana (common name: bullfrog). Taxonomically, all larvae obtained from the positive two frog species were identified as AdL3 of G. nipponicum. The bodies of the larvae from $R$. nigromaculata and $R$. catesbeiana were 1.10 $\times 0.11 \mathrm{~mm}$ and $0.72-2.03 \times 0.08-0.27$ (mean: $1.45 \times 0.16$ ) $\mathrm{mm}$, respectively. The mean body sizes of the larvae from $R$. catesbeiana were larger than those of larvae $(1.16 \times 0.14$ $\mathrm{mm}$ ) from naturally infected loaches (Misgurnus anguillicaudatus) in the same areas [13]. They had three rows of hooklets on the head-bulb, and the mean number of hooklets of each row from 1 st to 3 rd was 31,34 , and 39. Other morphological features of the present larvae coincided well with the descriptions of AdL3 of G. nipponicum from loaches reported by previous investigators $[3,9,13]$. Before our present study, spontaneous infection of larval $G$. nipponicum had not been reported from frog species. Thus, this is the first record of naturally infected $R$. nigromaculata and $R$. catesbeiana with this larvae.
The infection rate was $0.2 \%(1 / 436)$ in $R$. nigromaculata and was $34.7 \%(51 / 147)$ in $R$. catesbeiana. The prevalence of larvae in $R$. catesbeiana was higher. The number of larvae per infected $R$. catesbeiana were 1 to 95 (mean: 8.7), and a total of 445 larvae were recovered (Table 1). We reported previously the infection rates of larval $G$. nipponicum in several kinds of freshwater fish and small wild mammals collected from the same areas in Aomori Prefecture, i.e., $0.18 \%$ in Tribolodon hakonensis, $1.0 \%$ in Misgurunus anguillicaudatus, 3.4\% in Chaenogobius urotaenia, 2.75\% in Oncorhynchus masou, $46.7 \%$ in Silurus asotus, $27.3 \%$ in Rattus norvegicus, and $72.5 \%$ in Chimarrogale himalayica $[10-13,15]$. In comparison with those data, it seemed that the prevalence in $R$. catesbeiana in this study was relatively higher level.

The relationship between the number of larvae and body length of $R$. catesbeiana is summarized in Table 2. Infected frogs were found to be longer than $8.0 \mathrm{~cm}$, and as the body length increased, so did the infection rate and mean number of larvae per frog. The prevalence of frogs larger than 14.1 $\mathrm{cm}$ in body length showed extremely higher levels, which is attributed to the feeding habits of the frog. In general, the young-adult and adult stages of $R$. catesbeiana are essentially carnivorous and they prey chiefly on insect, fish, amphibians, reptiles, and small mammals such as voles, although the neonatal and juvenile stage (tadpole) are usually herbivorous. In fact, by examination of the stomach in this study, various food such as insects, insect larvae, and their body components were found commonly in 56 frogs. Additionally, ingested frogs (22 cases), small fishes (5 cases), loaches (3 cases) (Fig. 1), crawfish (3 cases), voles ( 3 cases), and a small sized snake ( 1 case) were also seen in frogs longer than $14.1 \mathrm{~cm}$ in body length. Therefore, we speculated that the most important direct sources to $R$. catesbeiana might be freshwater fish, such as loaches (Misgurunus anguillicaudatus) and gobiid fish (Chaenogobius urotaenia), based on the results of our previous surveys in the same localities. From this viewpoint, it was considered that $R$. catesbeiana was one of the paratenic hosts infected secondarily with AdL3 by eating the second intermediate hosts. In addition, it also suggested that $R$. catesbeiana has characteristics suitable to be the host to AdL3 of this nematode. While only one positive 


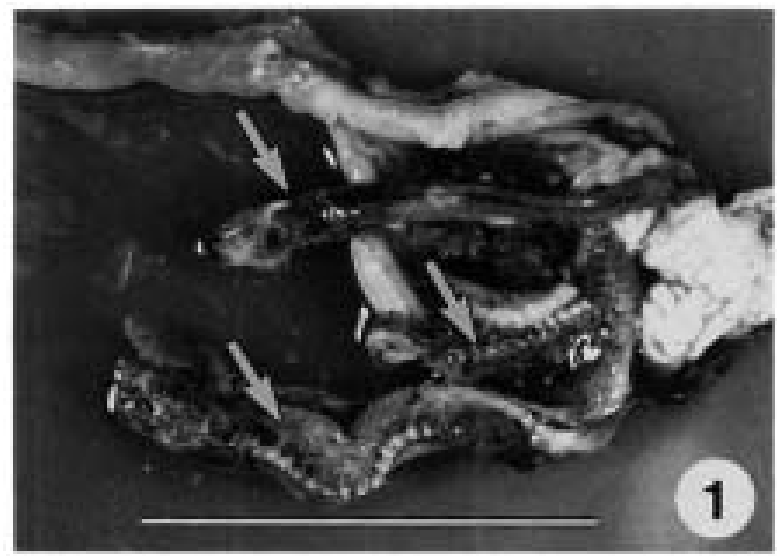

Fig. 1. View of the stomach in a Rana catesbeiana (Bar=5 $\mathrm{cm}$ ). Ingested food showing three loaches (arrows).

case of $R$. nigromaculata was small, measuring $3.0 \mathrm{~cm}$ in body length, the direct source was unclear whether the first or the second intermediate host. However, it seemed that this frog was infected accidentally with larva by eating the first intermediate host such as copepods than the second intermediate host, owing to recovered larva size, body size of infected frog, and feeding habits of this frog species.

In the examinations to determine the location of the larvae in $R$. catesbeiana, the vast majority of the larvae, 386 of $445(86.7 \%)$ were recovered from the musculature. By pressing examination of the three positive $R$. catesbeiana, four encapsulated larvae were clearly found within the musculature (Fig. 2).

The other three species of frogs, one of toad, and tadpoles in this study were all negative. It is unknown whether such negative data result from their non-susceptibility to this larval infection or their feeding habits. Further detailed studies are necessary to clarify the potential characteristics of these frog species and tadpoles to larval G. nipponicum infection.

The experimental study revealed that three species of small laboratory mammals were susceptible to AdL3 of $G$. nipponicum from $R$. catesbeiana. All 10 animals inoculated with AdL3 became positive, and recovery rates of the larvae were $57.5 \%$ in mouse, $35.0 \%$ in rat, and $20.0 \%$ in golden hamster at 30 days postinoculation. Most of the larvae (47/ 50: $94.0 \%$ ) were recovered from the body muscles. The morphological features of the larvae was similar to those of AdL3 before inoculation. However, body size of the larvae from three mammal species showed slightly development, and they measured $1.60-1.66 \times 0.16-0.18 \mathrm{~mm}$. From these results, it seemed that the AdL3 in $R$. catesbeiana were able to infect weasels and also to develop into the adult worms in their final host.

The present study confirmed that two frog species, $R$. nigromaculata and $R$. catesbeiana, infected with $G$. nipponicum larvae exist in nature. In addition, it also suggests that $R$. catesbeiana may be important sources of

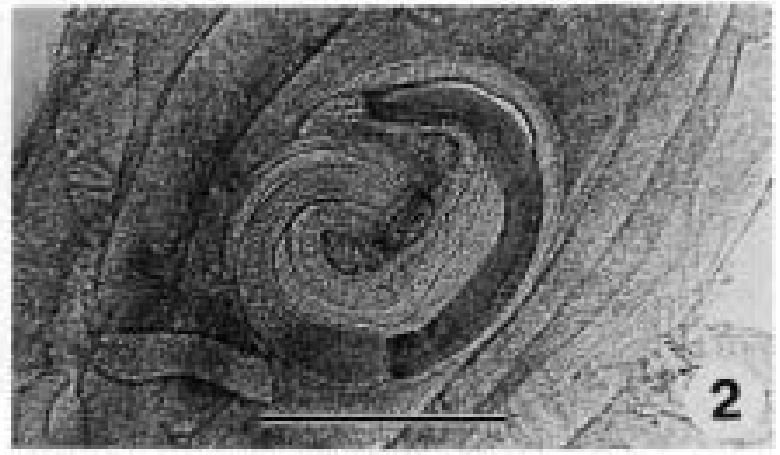

Fig. 2. An encapsulated larva found within the muscle of a Rana catesbeiana $(\mathrm{Bar}=300 \mu \mathrm{m})$.

infection to the weasels in conjunction with their feeding habits, and they may serve as the plausible second intermediate and/or paratenic hosts in the natural life cycle of this nematode.

\section{REFERENCES}

1. Akahane, H., Iwata, K. and Miyazaki, I. 1982. Jpn. J. Parasitol. 31: 507-516 (in Japanese with English abstract).

2. Ando, K., Tokura, H., Matsuoka, H., Taylor, D. and Chinzei, Y. 1992. J. Helminthol. 66: 53-61.

3. Ando, K., Tanaka, H., Taniguti, Y., Shimizu, M. and Kondo, K. 1988. J. Parasitol. 74: 623-627.

4. Hasegawa, H. and Otsuru, M. 1985. Jpn. J. Parasitol. 34 (Suppl. 56): (in Japanese).

5. Hasegawa, H., Otsuru, M. and Asato, R. 1982. Jpn. J. Parasitol. 31 (Suppl. 53): (in Japanese).

6. Kikuchi, T. 1956. Acta Med. 26: 2943-2970 (in Japanese with English abstract).

7. Koga, M. and Ishii, Y. 1981. J. Parasitol. 67: 565-570.

8. Koga, M., Ishibashi, J., Ishii, Y., Hasegawa, H., Choi, D. W. and Lo, T. Y. 1985. Jpn. J. Parasitol. 34: 361-370 (in Japanese with English abstract).

9. Miyazaki, I. 1966. pp. 531-586. In: Progress of Medical Parasitology in Japan, vol. 3. Megro Parasitological Museum, Tokyo.

10. Oyamada, T., Esaka, Y., Kudo, N., Oyamada, T., Yoshikawa, T. and Kamiya, H. 1996. Jpn. J. Parasitol. 45: 201-206.

11. Oyamada, T., Kobayashi, H., Kindou, T., Kudo, N.,Yoshikawa, H. and Yoshikawa, T. 1996. J. Vet. Med. Sci. 58: 839-843.

12. Oyamada, T., Kawagoe, T., Matsunaga, T., Kudo, N., Yoshikawa, H. and Yoshikawa, T. 1995. Jpn. J. Parasitol. 44: 283-289.

13. Oyamada, T., Kudo, N., Sano, T., Narai, H. and Yoshikawa, T. 1995. Jpn. J. Parasitol. 44: 222-227.

14. Oyamada, T., Kudo, N., Sakashita, H. and Yoshikawa, T. 1995. Jpn.J. Parasitol. 44: 128-132.

15. Oyamada, T., Kudo, N., Yoshikawa, H., Oyamada, T., Yoshikawa, T. and Suzuki, N. 1997. J. Vet. Med. Sci. 59: 671-675.

16. Sato, H., Kamiya, H. and Hanada, K. 1992. J. Parasitol. 78: 1006-1010.

17. Yamaguti, S. 1971. Jpn. J. Zool. 9: 409-440. 